\title{
Identification of the Airport's Environmental Issues (Case Sam Ratulangi International Airport of Manado)
}

\author{
Daniel Sondakh ${ }^{1,2}$, Maryunani ${ }^{3}$, Soemarno $^{4}$, Budi Setiawan ${ }^{5}$ \\ ${ }^{1)}$ Doctoral Program of Environment and Development Studies, PPS Brawijaya University, Malang, Indonesia \\ ${ }^{2)}$ Department of Civil Engineering, Faculty of Engineering, Tomohon Indonesia Christian University, Indonesia \\ ${ }^{3)}$ Department of Economics, Faculty of Economics and Business, Brawijaya University, Malang, Indonesia \\ ${ }^{4)}$ Department of Soil Science, Faculty of Agriculture, Brawijaya University, Malang, Indonesia \\ 5) Faculty of Agriculture, Brawijaya University, Malang, Indonesia
}

\begin{abstract}
This study aims to map the environmental issues that occurred at the Sam Ratulangi International Airport of Manado, so those environmental issues can be seen where that has got the proper treatment and which ones still need more attention. This research uses Importance-Performance Analysis. This analysis used to compare between the respondent's assessments of the environmental quality importance with performance levels of environmental quality. Performance improvement priorities are determined by the relative value only, which is the average value of importance and performance. Outcome mapping environmental issues is Quadrant I indicated that issues related to air pollution, noise, organic waste, health and the society economy improvement still needs to get more intensive handling priority again. Quadrant II shows that issues of vibration, organic waste, hazardous waste, flora and fauna have to maintain its performance by management Sam Ratulangi Airport. Quadrant III shows that the issue of socio-cultural influence is felt less important by the respondents. Whereas in Quadrant IV, not found any environmental issues. By implication, necessary to conduct more intensive control operations impact the airport, among others, the reduction of resource consumption, air and sound pollution control and waste management/waste operations.
\end{abstract}

Keywords: Airport Environmental Issues, Importance-Performance Analysis.

\section{Introduction}

Currently many airports face some problems resulting from its operational activity, such noise that comes from aircraft engines; air pollution and ground handling vehicles; as well as traffic jams caused by the large number of vehicles that enter or exit the airport. These things then it may cause impact on workers, communities, and the environment around the airport, so the airport operator is expected to prevent and reduce noise pollution, taking advantage of widespread use of land around the airport, developing regional relations towards other airports, and develop the airport area of harmony.

According to data from IATA aviation sector contributed for 12\% of global CO2 emissions in 1990 (IATA, 1991). Meanwhile, according to the Inter governmental Panel on Climate Change predicted by 2050 ahead, $\mathrm{CO} 2$ emissions caused by aviation activity will grow from 2 to 10 times when compared to emissions in 1992 (IPCC, 1994). In addition to producing CO2 emissions, aviation activity also generates NOx, VOC, CO and $\mathrm{SO} 2$. Most of the pollutants emissions from aviation activities are $\mathrm{CO} 2$, but its contribution is almost equal to the emissions of NOx (can be up to $23 \%$ ).

Airport environmental management are regulated by the Regulation of the Republic of Indonesia No. 40/2012 on the Airport Development and Environment Preservation, which is an Airport Operator is obligated to keep the threshold of noise and environmental pollution at the airport and surrounding area in accordance with the thresholds and raw quality imposed Government (article 31). According to the regulation, the environmental pollution at the airport are divided into 5 categories, are: (1) exhaust gas and noise emissions of aircraft operation; (2) exhaust emissions and noise from equipment and/or motor vehicles; (3) waste water arising from the construction, operation and maintenance of airports and aircraft; (4) solid waste arising from the construction, operation and maintenance of airports and aircraft; and (5) chemical substances arising from the construction, operation and maintenance of airports and aircraft (article 38).

Currently, airport operational activities does not focus on the movement of passengers and goods, but also of environmental quality control system should be given high priority, such as waste management and other environment-friendly activities (Muliasari, 2010). Environmental pollution that occurred at the airport can be a sound pollution (noise) and air pollution arising from the main pollutants emitted from aircraft gas emissions such as nitrogen oxide, carbon monoxide, carbon dioxide and sulfur dioxide (Masrifah. S, 2007). In addition there are also several sources of emissions of harmful air pollutants from airport vehicles or equipment, such as baggage transport vehicles and ground support equipment (GSE), the use of solvents, the aircraft itself, cars, buses, shuttles, etc (Wood et al., 2008). The research of "Air Pollutions: Exposing Airports Poison Circles" 
showed that residents living within a radius of 6 miles from the airport is exposed to a high risk of cancer caused by aircraft's exhaust gas emission, ground handling vehicles and airport maintenance activities. While the potential of cancer for people living around Chicago O'Hare Airport to 70\% higher than the average resident of Chicago. Jet planes pollute more while in the ground than in the air. The emissions of hydrocarbons and carbon monoxide occurs not less than 90\% when planes are idling and taxiing (Skolnick. S. R, et al, 2001).

Noise and vibration are the unwanted impacts of an Airport environment caused by operational activities of the airport affects the activities of an airport employee (ground handling) and also the residents in the vicinity of the airport (Sasongko et al, 2000). Noise has increased during the last few years, both caused by road traffic noise as well as aircraft (Vogiatzis, 2012). The main sources of noise and vibration are from aircraft in the air, aircraft slowed down after landing, aircraft on the ground, aircraft taxi time, electric generator operation, road traffic to and from the airport, as well as construction activities (Adisasmita, s. a., 2010). Aircraft noise could potentially interfere with everyday activities (such as communication and relaxation) of people living around the airport and potentially also damaging the quality of life as well as being the cause of stress (Issarayangyun, 2005). The noise also has been a problem for the environment, even since 1969, when operation Comet 4 and B707 begun, United States Government issued a regulation about noise, FAR Part 36, and stated that the noise has become a serious problem for the environment around the Airport (Green, 2003). Each aircraft movement can cause a negative impact on the environment (Issarayangyun et al., 2005). Consequently, the impacts occur due to operational activities of the airport, early should be anticipated (Luther, 2007).

Based on the above description of existing environmental problems need to be clearly mapped so that it can be formulated an improvements strategy appropriately and effectively. Therefore purpose of this research is to map the issues and environmental problems that occurred at the Sam Ratulangi International Airport of Manado.

\section{Research Object}

\section{Methodology}

In order to approach the environmental quality can be measured by the perceptions of the community who feel the quality of the environment of the airport. Therefore the observations made to the community who live around the Sam Ratulangi Airport of Manado within a radius of less than $5 \mathrm{~km}$.

\section{Data Collecting and Sampling Method}

Data collection techniques used in this research is a survey, interviews, observation and documentation in order to obtain the data and information required. Whereas the instruments that are used to retrieve data is structured questionnaire, where the details of the questions developed from the research variables formed from previous studies and amount of related Legislation dan Regulation of Republic of Indonesia. Likert scale instrument is used. The answers of questions consists of five levels, namely the "strongly agree", "agree", "moderately agree", "disagree", "strongly disagree". The assessment was given a fifth score as follows: (1) answer "strongly agree" was given a score of 5; (2) answer "agree" score 4; (3) answers "fairly disagree" score 3; (4) answers "do not agree" 2; (5) an answer of "strongly disagree" score 1.

As for the determination of the respondents number is carried out using the Slovin formula, as follow

$$
n=\frac{N}{1+N \cdot e^{2}}
$$

where: $\mathrm{n}=$ sample size; $\mathrm{N}=$ population size; $\mathrm{e}=$ error tolerance.

The respondents in this study are the population that settled in four (4) location adjacent to the Airport of Sam Ratulagi Manado, i.e. Koka Village with a population of 6,329 inhabitants; Paniki Perumnas II as much as 5,203 inhabitants; the village of Wusa 2,876 inhabitants and the village Winetin 1,956 inhabitants. So the Total population is 16,364. Sampling error can be tolerated taken $5 \%$. By using the Slovin formula above retrieved amount of respondent:

$$
n=\frac{16.364}{1+16.364 \times(0,05)^{2}} \quad=376,96 \approx 377 \text { respondents }
$$

\section{Variables Selection}

The variables examined were developed from the results of previous research and literatures, such as government regulation and textbooks related to the airport environment management, as on table 1 below: 
Tabel 1 Research Variabeles

\begin{tabular}{|c|c|c|c|c|}
\hline No & Variable & No & Attributes & Source \\
\hline \multirow{3}{*}{1} & \multirow{3}{*}{$\begin{array}{l}\text { Air Pollution and } \\
\text { Noise }\end{array}$} & 1 & Air Pollution & $\begin{array}{l}\text { Govenment Regulation No 40/2012; Maarifah. S, 2007; Wood et al; 2008, } \\
\text { Skolnick. S.R, et al, } 2001 \text {. }\end{array}$ \\
\hline & & 2 & Noise & $\begin{array}{l}\text { Govemment Regulation No 40/2012; Sasongko et al, 2000; Vogiatzs, 2012; } \\
\text { Adisamita, S.A. 2010; Issarayangyun, 2005; Green, 2003; Luther, } 2007 \text {. }\end{array}$ \\
\hline & & 3 & Vibration & $\begin{array}{l}\text { Govemment Regulation No 40/2012; Granà, at al 2011; Doddy, 2012; Tumer } \\
\text { et al, 2007; Lau at al, 2010. }\end{array}$ \\
\hline \multirow{3}{*}{2} & \multirow{3}{*}{$\begin{array}{l}\text { Water and Soil } \\
\text { Pollution }\end{array}$} & 4 & Organic wastes & $\begin{array}{l}\text { Govemment Regulation No 40/2012; Nelms, 1993; Pitt, et al, 2002; Doganis, } \\
\text { 1992; Gohnson dan Pedoe, 1996; Grantham, 1996; Sulej et al, 2012; Masrifah } \\
\text { S, } 2007 \text {. }\end{array}$ \\
\hline & & 5 & Non-organik wastes & $\begin{array}{l}\text { Govemment Regulation No 40/2012; Sulej et al, 2012; Masifah. S, 2007; } \\
\text { Grantham. 1996; Pitt, et al, 2002; Nelms, 1993; Doganis, } 1992 \text {. }\end{array}$ \\
\hline & & 6 & Hazardous wastes & $\begin{array}{l}\text { Govemment Regulation No 40/2012; Gohnson dan Pedoe, 1996; Grantham, } \\
\text { 1996; Pitt, et al, 2002; }\end{array}$ \\
\hline \multirow{2}{*}{3} & \multirow{2}{*}{ Environment } & 7 & Flora & Govenment Regulation No 40/2012. \\
\hline & & 8 & Fauna & Govemment Regulation No 40/2012; Masrifah. S, 2007 \\
\hline \multirow{3}{*}{4} & \multirow{3}{*}{ Social community } & 9 & Health & $\begin{array}{l}\text { Govemment Regulation No 40/2012; Issarayangyun, 2005; Skolnick. S.R, et } \\
\text { al, 2001; Sasongko dkk, } 2000 \text {. }\end{array}$ \\
\hline & & 10 & $\begin{array}{l}\text { Society Economy } \\
\text { Improvements }\end{array}$ & $\begin{array}{l}\text { Govemment Regulation No 40/2012; Elkington, 1997; Zhegal dan Ahmed, } \\
1990 ; \text { Nur R. TH. 2004. }\end{array}$ \\
\hline & & 11 & Culture & Govemment Regulation No 40/2012; Elkington, 1997; Francis et al. 2002. \\
\hline
\end{tabular}

\section{Analysis Method}

This research method using Importance-Performance Analysis. The Importance Performance Analysis (IPA) is a tool in line with the expectations-performance approach to the measure of quality perceptions. Since this approach was proposed by Martilla and James (1977), academic literature is replete of studies which provide empirical application in several service settings, such as transportation, banks, universities, hospitality and tourism. In its typical version, IPA involves assessing different aspects of an organization's features in terms of customers' perceptions of performance and of the importance of these performance.

Usually such features are represented in a $2 \times 2$ grid, where each quadrant can be summarized into a specific suggestion for management in particular, poor performance on extremely important dimensions indicate high priority in intervention for improvement ("Concentrate here" quadrant); excellent performance on highly important features represent opportunities for gaining or maintaining a competitive advantage ("Keep up the good work" quadrant); slightly important features that are excellent in performance imply that resources would be better employed elsewhere ("Possible Overkill" quadrant); finally, fair performance on slightly important features suggest that it may not be necessary to focus additional effort to these attributes ("Low priority" quadrant). Although the application of IPA has always been considered very simple and intuitive, over the years several different approaches to inferring priorities and measuring importance have emerged in the literature. This research used indirect measures to infer importance scores, with an overall performance measure as the dependent variable and the performance scores of single features as the independent variables. Positioning the vertical and horizontal axes on the grid is matter of judgment; specifically, in some applications the point where the quadrant lines cross is placed in the centre of the scale used ("scale-centred approach"), while in other studies the cross point is posited at the centre of data ("data-centred approach"). This study the crosspoint was set at the mean importance and mean performance values.

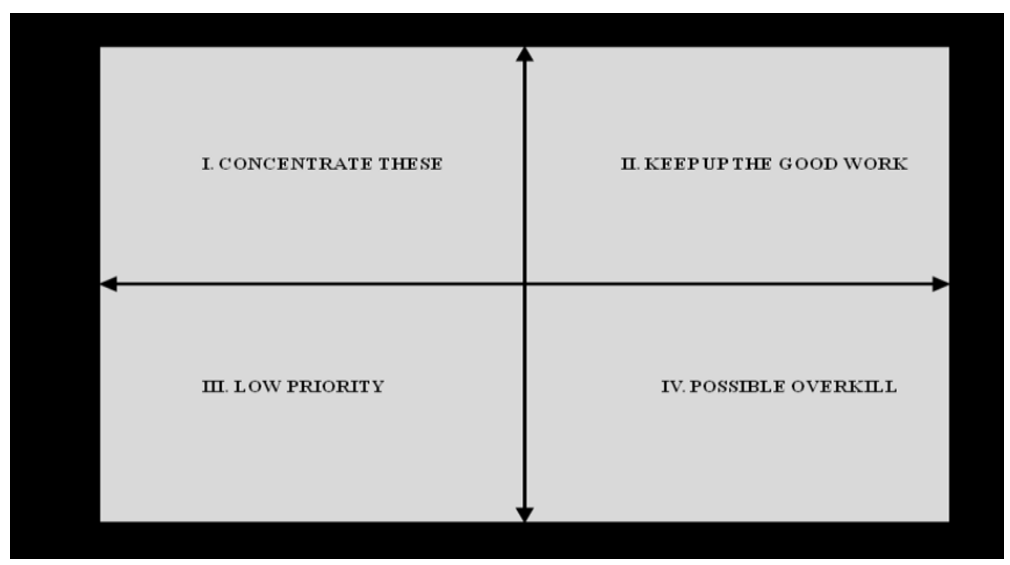

Figure 1. Importance Performance Scheme 


\section{Results and Discussion}

\section{General Profile of Sam Ratulangi International Airport of Manado}

Sam Ratulangi International Airport is located to the southwest of the city of Manado is $13 \mathrm{Km}$ from zero point downtown of Manado, at a height of 264 feet above Mean Sea Level. Administratively, Sam Ratulangi airport in Manado is comprised 188,20 Ha of The municipality of Manado and $46 \mathrm{Ha}$ of North Minahasa Regency, in total 234,20 $\mathrm{Ha}$. Most of them is in the village of Lapangan and West Mapanget, Mapanget district, and most are located in the village of Wusa and Winetin, Dimembe district, North Minahasa Regency.

Sam Ratulangi airport has a single runway with dimensions of $2,650 \mathrm{~m} \times 45 \mathrm{~m}$, azimuth $18-36$, overrun $60 \mathrm{~m} \times 45 \mathrm{~m} \times 2$, power/capacity PCN-72/F/C/X/T, after the overlay of 2010 , PCN up to $80 / \mathrm{F}$ a/X/T, 18-36 designation and equipped with overrun at both ends of the runway, each $60 \mathrm{~m} \times 45 \mathrm{~m}, 4$ taxiways, and 1 parallel taxiways $104,657.73 \mathrm{~m} 2$, passenger terminal of $25,063.77 \mathrm{~m} 2$, parking the vehicle in front of the passenger terminal of $8,074 \mathrm{~m} 2$, Cargo Warehouse 3,546 m2, parking the vehicle terminal and a cargo warehouse 16,944.48 $\mathrm{m} 2$ and Ground Service Equipment (GSE) 2,092.20 m2 with position is located on the left side of Mount Klabat is dealing with mount Lokon from South runways. Currently able to accommodate aircraft grade A-330. Position the apron is to the West with the distance from the runway center line to the edge of apron along the Spacious $212 \mathrm{~m}$. Apron area $=73,181.21 \mathrm{~m} 2$ after the expansion turns into 89,424.26 $\mathrm{m} 2$ and able to accommodate two aircraft type DC-10, 10 aircrafts type B737/MD-82 and 6 types of Cassa. In addition to civil aviation is also used for military flights by the Indonesian Air Force and the Indonesian Navy. Flight route to and from the Sam Ratulangi airport in Manado is served by several airlines, among others: Garuda Indonesia; Lion Air; Batavia Air; Sriwijaya Air; Wings Air; Express Water; Transwisata Water; Merpati Air and Silk Air.

The various activities carried out at the operational stage is: the operation of the Runway, Taxiways and Apron is a service of the movement of an aircraft on landing or takeoff and aircraft parking, where airport operating hours is set based on the Rgulation of the Director General of Air Transportation No. SKEP/24/II/2006 10 February 2006, i.e. from 23: 00-13: 00 UTC or 07.00-21.00 LT daily, the parties have requested the extension of the flight time (extend advance) from 21.00 to 06.00: Wita.

Passenger and cargo Services. Based on data for the period July - December 2011 for domestic and international flights were obtained the following data: the movement of aircraft or flight 8,250 total average per day 46 movements/day; 965,067 total passenger movement of people or an average 5,362 pax per day; The total amount of luggage $9,903,067 \mathrm{~kg}$ or average $55,017 \mathrm{~kg} /$ day; The amount of cargo total $6,935,866 \mathrm{~kg}$ or average $32,593 \mathrm{~kg} / \mathrm{day}$; The total number of Postal $153,222 \mathrm{~kg}$ or an average of $852 \mathrm{~kg} /$ day.

In support of government programs related to environmental preservation, in running an airport management business, PT Angkasa Pura Airports (Persero) still pays attention to environmental aspects of this case in accordance with the plan of the construction of the airport had been referring to the concept of eco airport in the design process and the selection of its material. Related socio-economic aspects, the company has been the realization of channeling funds of Rp. 38.8 billion for Partnership Program and Environment Development, which includes the construction of public facilities, education and preservation of the environment in the form of planting trees on 118,000 in several location surround the airports.

\section{Airport Environment Quality Asessment based on Public Perceptions}

Assessment of environmental quality of Sam's Ratuangi international airport of Manado is done based on perception of the communities that live around the airport. This is done in order to confirm the results of measurements of the same thing that is poured in the Airport Environment Monitoring Report of Sam Ratulangi.

Tabel 2. Score Calculation for Performance dan Importance

\begin{tabular}{|c|c|c|c|c|c|}
\hline \multirow{2}{*}{ Variables } & \multirow{2}{*}{ No } & \multirow{2}{*}{ Attributes } & \multicolumn{2}{|c|}{ Mean score } & \multirow{2}{*}{ Satisfaction } \\
\hline & & & Performance (X) & Importance (Y) & \\
\hline \multirow{3}{*}{$\begin{array}{l}\text { Air Pollution and } \\
\text { Noise }\end{array}$} & 1 & Air Pollution & 3,13 & 4,79 & $65,22 \%$ \\
\hline & 2 & Noise & 2,54 & 4,63 & $54,95 \%$ \\
\hline & 3 & Vibration & 4,38 & 4,71 & $92,92 \%$ \\
\hline \multirow{3}{*}{$\begin{array}{l}\text { Water and Soil } \\
\text { Pollution }\end{array}$} & 4 & Organic wastes & 2,96 & 4,77 & $62,01 \%$ \\
\hline & 5 & Non-organik wastes & 3,77 & 4,65 & $81,17 \%$ \\
\hline & 6 & Hazardous wastes & 4,42 & 4,77 & $92,58 \%$ \\
\hline \multirow{2}{*}{ Environment } & 7 & Flora & 4,88 & 4,73 & $103,08 \%$ \\
\hline & 8 & Fauna & 4,25 & 4,83 & $87,93 \%$ \\
\hline \multirow{3}{*}{ Social community } & 9 & Health & 3,38 & 4,69 & $72,00 \%$ \\
\hline & 10 & $\begin{array}{l}\text { Society Economy } \\
\text { Improvements }\end{array}$ & 3,23 & 4,81 & $67,10 \%$ \\
\hline & 11 & Culture & 3,17 & 3,90 & $81,28 \%$ \\
\hline \multicolumn{3}{|c|}{ Rata-rata } & 3,64 & 4,66 & $78,18 \%$ \\
\hline
\end{tabular}


Next those elements are elaborated into four (4) parts on a Cartesian diagram. The position of each attribute in the four quadrants can be made into a tool for composing an improvement strategy alternate.

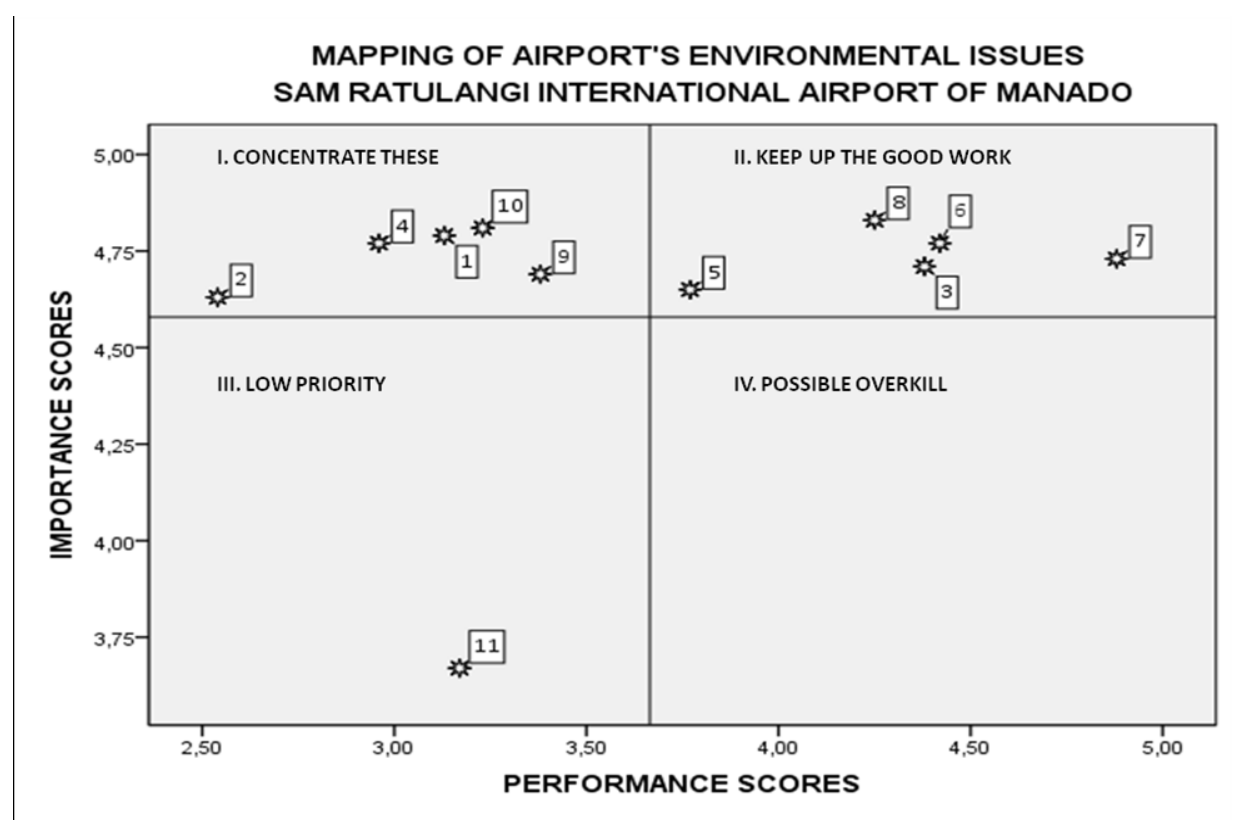

Figure 3. Cartesius Diagram of Importance and Performance Analysis

Remarks:

$\begin{array}{llllll}\text { 1. } & \text { Air pollution } & 5 . & \text { Non-organik wastes } & 9 . & \text { Health } \\ \text { 2. } & \text { Noise } & 6 . & \text { Hazardous wastes } & 10 . & \text { Society Economy Improvements } \\ \text { 3. } & \text { Vibration } & 7 . & \text { Flora } & 11 . & \text { Culture } \\ \text { 4. } & \text { Organic wastes } & 8 . & \text { Fauna } & & \end{array}$

Interpretation of Importance and Performance Analysis, as follows:

1) Quadrant I (Concentrate These). This quadrant shows the factors or attributes that affect performance are considered environmental quality of Sam Ratulangi Airport, but the management has not been able to put into practice the most appropriate standards that exist. It is therefore necessary to handle priority and improved so that it can enter into the quadrant II. Attributes included in this quadrant are: air pollution, noise, organic waste, Health and Society economy improvements.

- This pollution caused by traffic, aircraft ground handling, operational vehicle traffic by land as well as by complementary activities at the Airport (café, restaurant, burning garbage, etc.). The resulting pollutants varies, but in general contain elements of carbon, hydrogen, nitrogen and lead, such as carbon monoxide, carbon dioxide, nitrous oxide, methane, and ammonia. Results of the measurement of some elements of the pollutants carried out relevant agencies showed the highest concentrations (although still below threshold) is the particle CO. Learn more see table 3 below

Tabel 3. Result of Air Pollutant Measurement in Sam Ratulangi Airport of Manado

\begin{tabular}{|c|c|c|c|c|c|}
\hline \multirow{2}{*}{\multicolumn{3}{|c|}{ Treshold }} & \multicolumn{3}{|c|}{ FY 2012} \\
\hline & & & Parking Area & Mapanget & Koka Village \\
\hline $\mathrm{SO}^{2}$ & 900 & $\mu \mathrm{g} / \mathrm{m}^{3}$ & 27.7 & 65.6 & 28.8 \\
\hline $\mathrm{NO}^{2}$ & 400 & $\mu \mathrm{g} / \mathrm{m}^{3}$ & 9.45 & 11.2 & 13.8 \\
\hline $\mathrm{CO}$ & 30,000 & $\mu \mathrm{g} / \mathrm{m}^{3}$ & 6857 & 5142 & 9142 \\
\hline $\mathrm{O}_{3}$ & 230 & $\mu \mathrm{g} / \mathrm{m}^{3}$ & 58.7 & 78.3 & 97.9 \\
\hline PM 10 & 150 & $\mu \mathrm{g} / \mathrm{m}^{3}$ & 14 & 28 & 39 \\
\hline PM 2,5 & 65 & $\mu \mathrm{g} / \mathrm{m}^{3}$ & 0 & 0 & 0 \\
\hline $\mathrm{Pb}$ & 2 & $\mu \mathrm{g} / \mathrm{m}^{3}$ & 0.8 & 0.9 & 1 \\
\hline
\end{tabular}

Source: Airport's Health Office of Manado

Overall, these air pollutants around the neighborhood Sam Ratulangi Airport is actually still under the threshold required. When conditions change based on the number of vehicles, passengers and cargo has 
increased then if there are increased levels of pollution from all the test parameters is the impact of the change in the condition.

- Noise. The source of the noise impact as long as it comes from the activities of the movement of an aircraft and land transport also comes out in the airport as well as the hours of operation of generator in case of a electricity blackout, operational equipment usage such as hold speaker, towbar, luggage-carrying train car, fuel tanks, and more. Based on the results of testing the quality of the noise made on four (4) points indicating the noise level above the raw quality of the required, especially in the residential of West Mapanget (Koka), Paniki Dua (Perumnas), the village of Winetin and the villages of Wusa. Peak noise levels occur at 24.00-01.00. If the average value, then taken on a span of 21.00-02.00 noise levels occur is $66,94 \mathrm{~dB}(\mathrm{~A})$. When compared with the results of the measurements at some other location, in general the noise level in the area of the airport still qualify but the noise levels that occur in the residential area around the airport was not eligible because it exceeds the default threshold noise levels for the settlement. Noise Quality standards for residential areas is $55 \mathrm{~dB}(\mathrm{~A})$, in accordance with the decision of the Minister of the environment no. 48/Men-LH/11/1996 on Noise level treshold.

- Organic Waste. Waste utilization activity is derived from the airport utilities (including aircraft), event catering, passenger activity and administrative activities of the office. This has the potential to waste polluting the surface water quality in the form of changes in the quality of Chemistry-Physics of surface water and the River in the vicinity of the airport due to the increasing content of organic chemistry/inorganic as TSS, BOD, COD, Mn, Sulfide, nitrites, Phenols, and benthos and plankton biota that the number will decrease. The issue is also getting complaints from people who lived in the vicinity of the airport, relating to the contamination of the river that flows through the settlements, it is generally said that the presence of water is not pure anymore (already contaminated organic waste). Based on a body of water quality monitoring data in four locations, there are a number of findings observations BOD and COD exceeding the thresholds obtained Water class II (Government Regulation No. 82/2001) that is $3 \mathrm{mg} / \mathrm{l}$ and COD of $25 \mathrm{mg} / \mathrm{l}$. Exhaust waste from STP (Sewage Treatment Plant) is large enough that the results obtained 27.4 BOD and COD 30.2. From the results of examination of wastewater retrieved results "not qualified" in the parameters of BOD and TSS. Likewise the TSS (Total Suspended Solid) obtained results of $720 \mathrm{mg} / \mathrm{l}$. High TSS is caused in the process of blowing up sewage, traffic-jammed because of frequent engine blower or the supply of waste effluents from sewage distribution at the airport terminal which does exceed the normal range. Whereas the possibility of induced factors other polluters because of wastes from houses around the river or the exile of pesticides from agriculture and animal husbandry of pigs in the village location not far from the river. Any complaints about the smell of excrement wafted up to the housing in the village of Koka (West Mapanget) is derived from the phase/process, i.e. when there is congestion blower (heatable waste), then the blower cover is opened to repair so the smell wafted out and stab into the residential area, given the location of the village of Koka is next with STP.

- Health. Air quality problem is suspected as a cause of potentially enough on human health are monitored at data from Airport's Health Office of Manado where in 2011, noted sufferer of disease respiratory tract infections as much as 188 cases, much bigger compared to other diseases. This corroborated the results of interviews with people who lived in the vicinity of the airport, particularly in the village of Koka, a part of the community complained of relates to the impact of air pollution, the smoke from the burning debris and smoke smelling fuel aircraft, which, according to their allegations led to respiratory failure and hypertension. It is then done to confirm data on Airport Health Office obtained information that this air quality problem is suspected as a cause of potentially enough on human health. which is monitored on the data the number of Patients and diseases suffered a period of January until June 2012 did show the highest disease are hypertension and respiratory tract infections. See table 4 below

Table 4 . Patient number dan Diseases

\begin{tabular}{|c|l|c|c|c|c|c|c|c|}
\hline \multirow{2}{*}{ No } & \multicolumn{2}{|c|}{ Diseases } & \multicolumn{9}{|c|}{ Months } \\
\cline { 3 - 9 } & & Jan & Feb & Mar & Apr & May & Jun & Total \\
\hline 1 & Diarrhea & 3 & 2 & 5 & 2 & 2 & 2 & 16 \\
\hline 2 & $\begin{array}{l}\text { Respiratory tract } \\
\text { infections }\end{array}$ & 10 & 9 & 13 & 7 & 8 & 6 & 53 \\
\hline 3 & Hypertension & 8 & 9 & 12 & 16 & 13 & 8 & 66 \\
\hline 4 & Heart disorders & 4 & 3 & 2 & 1 & 4 & 2 & 16 \\
\hline 5 & Diabetes & 4 & 4 & 1 & 2 & 1 & 0 & 12 \\
\hline 6 & Work accident & 0 & 0 & 0 & 1 & 0 & 1 & 2 \\
\hline & Total & 29 & 27 & 33 & 29 & 28 & 19 & 165 \\
\hline
\end{tabular}

Source: Airport's Health Office of Manado 
While the potential effects of noise on human health can occur in the form of psychological disorders, physiological and pathological. Eny Hastuti (2004) conducted a study on worker Ahmad Yani Airport in Semarang found levels of intensity noise in excess of $85 \mathrm{~dB}(\mathrm{~A})$, has increased the risk for systolic blood pressure of 2.5 times and rise in diastolic blood pressure of 2.1 times compared to workers who are exposed to noise less than $85 \mathrm{~dB}$ (A). Jennie Babba (2007) conducted a study on 60 workers who get the exposure to noise of Cement Tonasa Factory, South Sulawesi. As a result, workers who are exposed to noise with an intensity of more than $85 \mathrm{~dB}(\mathrm{~A})$ an increase in systolic blood pressure of 10.5 times and an increase in diastolic blood pressure of 7.6 times compared to workers with exposure to less than $85 \mathrm{~dB}(\mathrm{~A})$.

Improving the society economic. This issue is related to the roles and responsibilities of companies (operators of the airport), namely Angkasa Pura Airports Corporation to its environment. As a business entity that should be managed professionally, the company claimed to be able to run the entire business and its operational activities on an sustainable basis. Because it's in a healthy company management efforts and sustained this then makes a profit is not the only goal, but companies are expected also to give attention to the improvement of the welfare of society (people) and environmental sustainability (planet). Management of the socio-economic impact on the Community by the management of PT. Angkasa Pura Airports (Persero) in Manado, among others, in the form of programs like empowerment of communities living around the Airport (community development) such as the provision of public facilities and social facilities around the airport, Corporate Social Responsibility, such as the improvement of infrastructures and means the economy, improvement of sanitary conditions of the environment, the creation of cultural preservation workshop, supplying medical facilities and medical personnel. From the data that was successfully obtained, noted that the Partnership Program have taken up a number of funds (until the end of 2012) amounted to Rp. 12,935,750,000 distributed to 670 partners assisted Angkasa Pura Airports Manado. From here the course expected this assisted the partners in time can actually survive, not easy shake by various economic storms and can mutually build synergy on the win-win solution. However it is still obtained the findings of complaints about the fund's channelling partnership program in the form of soft loans which are not evenly distributed, there is a tendency of favoritism or intended only for relatives only. According to the observations turned out to be not all incoming proposals it surveyed so that things happen that are said to be "not fair" or "favoritism". As it was said some villagers Koka, "we are the location adjacent to the runway and we've been twice asking two proposals but there has been no response until now, they were (Angkasa Pura) is indeed "not fair". The management of Angkasa Pura would quibble that they have sought a maximum in distribution, but it should be recognized that many forms of this type of business that appeared suddenly at the time of the survey months, the rest of the business is gone.

2) Quadrant II (Keep up the Good Work), shows the attributes that are considered important by the respondent and has been implemented by the management, so that respondents expressed satisfaction to the attributes that are in the quadrant II. Therefore, attributes are present in this quadrant have defended its performance in the management of the Sam Ratulangi Airport in Manado, which in this case has done the right things against attributes so that they can meet the standards in force. These attributes are the attributes of vibration, trash, waste organic B3, the Flora/Fauna.

3) Quadrant III (Low Priority). In this quadrant there are attributes that have performance and relatively low importance, in other words this attribute less important influence is felt by respondents. The attribute is socio-cultural (Attribute 11)

4) Quadrant IV (Possible overkill), shows the attributes that are considered less important by the respondents, but its performance is judged either overdoing or perceived. This quadrant is not found on any of the attribute.

\section{Managerial Implications}

Airport operations impact on the control environment in order to support sustainable development, among others, a reduction in the use of resources, the control of air pollution and noise. It is based on the issues of "sustainability" which is not only focused on technical aspects, but also an environmental, a societal and economic performance dimension in order to increase capability.

To further reduce the number of air pollution and noise, then Angkasa Pura Airports need to intensify or reproduce any more plants/trees of certain types in the vicinity of the road leading to the airport and also developed planting plants on a buffer zone bordering localities can serve as a sound damper air pollution and noise. Some other ways to overcome or reduce the level of noise and air pollution are rearranging the landscape, land use planning, use and reproduce the noise reducer building trees planted at a distance of just meeting. Planting trees can be used for comparison of embankment width and height is 1: 4 slope on both sides is 1: 2 (Lord and Templeton, 2001). As for building noise reducer can be based on Regulation of the Director-General of Bina Marga No. 076/KPTS/Db/1999, concerning guidelines on Planning Techniques, Building Silencer Noise where height arranged a minimum of $2.75 \mathrm{~m}$, and a wall thickness of at least $10 \mathrm{~cm}$. other methods are quite 
effective in order to reduce the impact of this is making land use planning-empty land around the Airport (Horonjeff, 1993). This was done also in order to reduce the impact of air pollution and noise for the people who lived in the vicinity of the airport can be minimised. With regard to the types of crops that can be used, it can refer to Regulation of Transportation Minister No. Km. 77/1998, about the kinds of plants or trees that can dampen noise, among others, johar, hibiscus tiliaceus, angsana, tanjung, kiara payung and glondongan as well as the types of plants that do not invite birds, like firs and pines of angina. Besides it can be carried out also fitting silencers on building administration offices, terminals and airport operational and reproduce the installation barrier and folders to reduce noise and exhaust gas from the aircraft.

The airport is essentially a small city, because it has a significant impact on the volume of waste generated (Nelms, 1993). In 1993, the Dallas Fort Worth International Airport in the United States produces about 300 thousand tons of waste, or the equivalent of a city with a population of 250,000 (Nelms, 1993). The main source of waste is the Office, which resulted in a large number of recycling waste such as paper, therefore reducing waste at the source (the principle of reuse) is an effective way to protect the environment, while also reducing the cost of disposal (Pitt, et al, 2002). In addition to this commercial activity is the second largest producer, then to minimize, the tenant should always be encouraged to reduce the production of discharge or recycle (Doganis, 1992). A number of airports in the United Kingdom has long been implementing recycling schemes in order to reduce the waste that is dumped (Wareing, in Pitt, 2010). The existence of an airport can provide benefits to the area and can also cause negative side effects, namely domestic waste that can pollute the environment pollution of groundwater, pollution of surface water/liquid waste and solid waste pollution (Masrifah. S, 2007). Because of it required continuous efforts in order to control the production of these wastes are from day to day would certainly be increased.

In addition, overall Airport operations expected to be friendly to the global environment issues, namely the reduction of the GHG (Greenhouse Gases) and a reduction in energy consumption. The resulting pollution from aircraft engines to note the bad impact on the environment, although "only" accounts for approximately 3\% (Doddy, 2012). So, the airport can be instrumental in reducing the impact of global climate change by means of controlling the emission of GHG resulting from airport ground transportation and reduce energy use in buildings as well as emissions-related indirect emissions (Kim et al., 2009a). On the utilization of energy, in general, almost all public services in Indonesia is quite wasteful energy consumption, so that the need for energy management. Energy use in airports, widely used in lighting systems, heating, ventilation, air conditioning and a system of conveyor belts, and the cost of energy is the second largest cost after employee costs on airport operations (Turner et al., 2007). For the building in terminal Airport (in the US) absorb 40\% of electrical energy. Some airport managers reduce the cost of operations through energy efficiency on the supply side and consumption (Lau et al., 2010). Kansai Airport in Japan conserved energy and emission reduction through the improvement of GHG facilities continuously to be able to control the annual CO2 emissions of 23,000 tons or equivalent of $26 \%$ of emissions at a time when the airport was first operated (Kansai Airport Management, 2012).

\section{Conclusions}

Outcome mapping of environment issues based on Importance and Performance Analysis showed that the factors contained in quadrant I (Concentrate These) still need to get management and better handling. Those factors are: Noise, air pollution, organic waste, health and society economy improvement. While the Quadrant II (Keep up the Good Work), shows the factors considered important by the respondent and has been implemented by the management, so that the respondent state is satisfied with respect to the factors that are at the quadrant II. Therefore, the management of Sam Ratulangi Airport in Manado must strive to maintain this performance. Those factors are attributes of vibration, Organic Waste, harmful waste, Flora and Fauna.

A challenge for PT. Angkasa Pura Airports (Persero) maintainers as airports in Central and eastern Indonesia Region is to meet and pay attention to these components in order to make the eco-friendly airport. Can or not will depend on the readiness and the understanding of all stakeholders. The existence of the airports development can give hope to anyone who hopes that the airport is able to compete with other international airports that have recognized their excellence services and predicates. In addition, also expected the grandeur that would later manifest will not intersect with environmental and social aspects of the society especially in the vicinity of the airport such as land acquisition, prosperity, and also the opening of employment.

\section{Referances}

[1]. Adisasmita, S.A, Achmad Zubair, 2010, “Aircraft Noise Level Impact At Airport And Its Surroundings, (Case Study: Djalaluddin Airport, Gorontalo, Indonesia)", Proceeding of Malaysian Universities Transportation Research Forum and Conferences 2010 (MUTRFC2010), 21 December 2010 Universiti Tenaga Nasional. ISBN 978-967-5770-08-1.

[2]. Ashraf, Jan, 2010, "Airport Systems: Planning, Design, and Management" American Planning Association. Journal of the American Planning Association· Autumn 2010; 70, 4; ProQuest.

[3]. Berry, F, Sarah Gillhespy, Jean Rogers, 2008, "Airport Sustainability Practices-A Synthesis of Airport Practice", Transportation Reasearch Board of The National Academies, Washington DC, (C) 2008 National Academy of Sciences. All rights reserved. 
[4]. Doddy, H, 2012, Reduce Emissions, Go Green Aviation, Accessed: http://doddyhw. wordpress. com/2012/10/11/ reduce-emissionsgo-green-aviation/.

[5]. Doganis, R, 1992,. "The Airport Business", Routledge, London.

[6]. Elkington. J, 2007, "Cannibals with Forks - The Triple Bottom Line of 21st Century Business", Capstone Publishing Ltd, Oxford.

[7]. Francis, G., Humphreys, I., Fry, J, 2002, “The Benchmarking of Airport Performance”. Journal of Air Transport Management 8, p 239-247, Elsevier Ltd.

[8]. Granà, A, Orazio Giuffre', 2011, "Managing Greenhouse Gas Emissions for Airport Inventories: An Overview", Journal of Sustainable Development Vol. 4, No. 5; October 2011, Published by Canadian Center of Science and Education.

[9]. Grantham, D., 1996, "Surface water contamination caused by airport operations", in Pedoe, N., Raper, D. and Holden, J. (Eds), "Environmental Management at Pura Airports", Liabilities and Social Responsibilities Conference, Manchester Airport, 1995, Thomas Telford, London, pp. 104-21.

[10]. Green, J. E, 2003 "Civil Aviation and The Environmental Challenge", The Aeronautical Journal, Vol. 11, No. 4/2013, p 325-339. Elsevier Ltd.

[11]. Issarayangyun, T. Black, J. Black, D. Samuels, S, 2005, "Aircraft Noise And Methods For The Study Of Community Health And Well-Being”, Journal Of The Eastern Asia Society For Transportation Studies, Vol. 6, p. 3293 - 3308.

[12]. Herndon. E.W.C, Richard Miake-Lye David Nelson and Mara Seeley, 2008, Aircraft and Airport-Related Hazardous Air Pollutants: Research Needs and Analysis, Aerodyne Research, Inc. Billerica, MA and Environmental Health \& Engineering, INC. Needham, MA.

[13]. Horonjeff, R \& McKelvey, F.X., 1988, "Perencanaan dan Perancangan Bandar Udara”. Penerbit Erlangga, Jakarta.

[14]. Kim, B., Bassarab, R. Vigilante, M., \& Waitz, I. A. (2009a). "Guidebook on Preparing Airport Greenhouse Gas Emissions Inventories", Transportation Reasearch Board of The National Academies, Washington DC, (C) 2008 National Academy of Sciences. All rights reserved.

[15]. KIX Management, 2012, "Kansai International Airport Environmental Management Projects", Kansai International Airport Co., Ltd., January 2012.

[16]. Lau, Craig R., Joel T. Stromgren, and Daniel J. Green, 2010, “Airport Energy Efficiency and Cost Reduction: A Synthesis of Airport Practice", Transportation Reasearch Board of The National Academies, Washington DC, (C) 2010 National Academy of Sciences. All rights reserved.

[17]. Luther, L., 2007, "Environmental Impacts of Airport Operations, Maintenance, and Expansion”, Environmental Policy Analyst Resources, and Industry Division, Editor.

[18]. Masrifah, S, 2007, "Manfaat Limbah Domestik di Bandara Soekarno Hatta, Jurnal Penelitian Perhubungan Udara, Vol 33, No 2, Desember 2007

[19]. Muliasari, A, 2010, "Kebutuhan Air Bersih dan Proses Penyaluran Air Buangan Bandara Soekarno Hatta" Jurnal Penelitian Perhubungan Udara Vol. 36 No.3, September 2010.

[20]. Nelms, D., 1993, "Waste not Want not: Airports and Airlines are Finding Better Ways to Rid themselves of Trash", Air Transport World, Vol. 30 No. 10, pp. 44(5).

[21]. Nur R. TH, 2004, "Evaluasi terhadap Pelaksanaan Komunikasi Pemasaran Sosial Non-Goverment Organization (NGO) untuk Isu-Isu Anti Kekerasan terhadap Perempuan”, Jurnal Ilmu Komunikasi Volume 1, Nomor 1, Juni 2004: 143-160.

[22]. Pison I., Menut L., 2004, "Quantification of The Impast of Aircraft Traffic Emissions on Tropospheric Ozone over Paris Area". Atmos. Environ. 38, 971, 2004.

[23]. Pitt, M. and Brown, A, 2001, “Measuring The Facilities Management Influence in Delivering Sustainable Airport Development and Expansion”, Facilities, Vol. 19 No. 5/6, pp. 222-32.

[24]. Pitt, M. Andrew Brown and Andrew Smith, 2002, "Waste managementat Airports", Facilities, Vol. 20, 516; pg. 198, ProQuest.

[25]. Sasongko D.P, Hadiyarto A, Sudharto P Hadi, Asmorohadi Nasio, Subagyo A, 2000, Kebisingan Lingkungan, Badan Penerbit Universitas Diponegoro, Semarang.

[26]. Skolnick, S.R, "Exposing Airports' Poison Circles", Earth Island Journal:Winter 2000-2001.

[27]. Skouloudis, A, Konstantinos E, Stavros M, 2012, "Accountability and Stakeholder Engagement in The Airport Industry: An Assessment of Airports' CSR Reports”, Journal of Air Transport Management 18 (2012) 16-20, Elsevier Ltd.

[28]. Sulej Anna, Żaneta Polkowska, Jacek Namieśnik, 2012, "Contaminants in Airport Runoff Water in the Vicinities of Two International Pura Airports in Poland", Polish Journal of Environmental Studies, Vol. 21, No. 3/2012, p 725-739. Elsevier Ltd.

[29]. Transportation D.O., 2008 "Management of Airport Industrial Waste" F.A. Administration, Editor.

[30]. Turner, W, Dan. Malcolm Verdict. Bahman Yazdani. Harold Huff. Kathryn Clingenpeel., 2007, "Model for Improving Energy Use in U.S. Airport Facilities", Research was performed under ACRP Project 11-02 by the Energy Systems Laboratory (ESL) within the Texas Engineering Experiment Station (TEES), located at Texas A\&M University, College Station, Texas, Transportation Reasearch Board of The National Academies, Washington DC, (C) 2007 National Academy of Sciences. All rights reserved.

[31]. Vogiatzis, Konstantinos, 2012, "Airport Environmental Noise Mapping and Land Use Management as an Environmental Protection Action Policy Tool-The Case of the Larnaka International Airport (Cyprus)", Science of the Total Environment, May 2012,Vol. 424, p162-173, 12p.

[32]. Wood, E. Herndon, S. Lye, RM. Nelson, D, 2008, “Aircraft and Airport-Related Hazardous Air Pollutants: Research Needs and Analysis", Airport Cooperative Research Program (ACRP), Transportation Research Board, Washington, D.C.

[33]. Zeghal, D. \& Ahmed, S.A. (1990). "Comparison of Social Responsibility Information Disclosure used By Canadian Firms", Accounting, Auditing and Accountability Journal, 3 (1), 38-53. (c) Emerald Group Publishing Ltd.

[34]. Legislation of the Republic of Indonesia No. 1/2009 on Aviation

[35]. Legislation of the Republic of Indonesia No. 32/2009 on Protection and Management of Environment

[36]. Regulation of the Transportation Minister of the Republic of Indonesia No. 11/2010 On National Airports Order.

[37]. Regulation of the Government of the Republic of Indonesia No. 40/2012 on the Airport Development and Environment Preservation.

[38]. Regulation of the Government of the Republic of Indonesia No. 70/2001 on the Airport. 